\title{
Estimated Cost of Repairing Road Pavement Damage Assessment: A Case Study of Indonesia
}

\author{
Edy Suhartono, Muhammad A, Renggananda BP, Martono, Marsudi \\ Dianita Ratna Kusumastuti, Dedi Budi Setiawan, Nur Setiaji P \\ Department of Civil Engineering \\ State Polytechnic of Semarang \\ Indonesia
}

\begin{abstract}
Road infrastructure is a land transportation infrastructure that affects the development of an area. When infrastructure is damaged, distribution between regions will be disrupted and have an impact on regional economic development, in addition to the inconvenience felt by road users. This condition occurs on provincial roads in Pemalang District which are damaged. Road damage was caused by the passing of the Pemalang-Batang Toll Road construction project so that the volume of vehicles passing exceeded the capacity of the road. The high growth of traffic because economic growth can cause serious problems if it is not balanced with the maintenance and improvement of the quality of existing road facilities and infrastructure. It is necessary to add road infrastructure and good pavement planning and sustainable road maintenance so that road conditions remain safe and comfortable to provide services for vehicle traffic. The purpose of this study is to find economic costs to repair road damage. The research method used is descriptive quantitative method. This research was conducted at Jalan Letjend DI Panjaitan in Pemalang District. From the results of this analysis, it was found that the damage that occurred on Jalan Letjend DI. Panjaitan in Pemalang District according to the Bina Marga method shows the number of road conditions $58.30 \%$ (good), 10\% (minor damage), and $31.60 \%$ (heavily damaged). Improvement methods for good road conditions and minor damage are Bina Marga Standards and repairs to heavily damaged road conditions using a rigid pavement method with a thickness of $25 \mathrm{~cm}$. Total budget of Rp. 2,880,928,554.00 can save 72.57\% compared to the calculation of Bina Marga Standards using overall pavement repairs.
\end{abstract}

Keywords : Jalan Pemalang Randudongkal, Damage and Repair of Road Pavement, Cost Estimates

\section{INTRODUCTION}

Road is an important infrastructure for the development and economic growth of a region because it is a system of land transportation networks. This can increase regional economic growth as well as facilitate the conditions for the transportation of goods and services. Because of this change, road infrastructure is often damaged from a small level of damage to a large degree of damage. According to (Saputro, 2014) Road damage can be divided into two parts, namely structural damage which includes pavement failure or damage from one or more pavement components which results in the pavement unable to bear the traffic load, and functional damage which includes safety and comfort. Road damage that occurs is a very complex problem and causes very large losses, especially for road users, such as the occurrence of long travel times, traffic jams, traffic accidents and others. This individual loss will be an accumulation of global economic losses for the region.

According to (Saudule, 2014) the causes of damage in general are an increase in traffic volume loads, poor drainage systems, poor material properties of pavement construction, climate, unstable soil conditions, very thin pavement planning, inappropriate work processes with specifications. This condition occurs on provincial roads, Jalan Letjend DI. Panjaitan Pemalang Regency is damaged. Damage to this road is due to the construction of the Pemalang-Batang Toll Road construction project so that the number of vehicles passing exceeds the capacity of the road. The damage factor results in a decrease in the quality and age of the 
road. J1. Letjend DI Panjaitan in Pemalang Regency is a class IIIA road with asphalt pavement, which is the main collecting road as the main route connecting Pemalang (Pantura) to Purwokerto. Often also used as a diversion route when the Pantura road is busy. Because the road needs are getting higher, it must be balanced with improving the quality of existing road facilities and infrastructure. Required addition of road infrastructure and good pavement planning and continuous road maintenance so that road conditions are safe and comfortable to provide services for vehicle traffic. The selection of the right road repair technique is done by assessing the condition of the road surface visually determined by the approach method that can be used in assessing road conditions. This study aims to determine how the surface conditions of the pavement and assess the condition of the pavement and to determine the appropriate repair techniques and economic costs for repairs needed along the way of the Lt. DI. Panjaitan Pemalang Regency using the Highway methods.

\section{RESEARCH METHODS}

\subsection{Place and time of research}

The research location that was used as the object of this research was Road Section Letjend DI. Panjaitan Pemalang Regency is 3 km long. When this research was conducted for 5 months. Starting from Monday February 19, 2018 to July $31,2018$.

\subsection{Research design}

The research method used is descriptive quantitative method. The selection of the right road repair technique is carried out by evaluating the condition of the road surface based on the type of damage that is visually determined by an approach method that can be used in assessing road conditions based on the City Road Maintenance Program Number: 018 / T / BNK / 1990 (Directorate of Highways, 1990).

\subsection{The scope of research}

The scope of this research is outlined as follows: The level of damage to roadwork on the Road Section of Letjend DI. Panjaitan Pemalang Regency; Appropriate repair techniques for handling damage that occurs in the Road Section of Letjend DI. Panjaitan Pemalang Regency; Costs needed for rehabilitation of the Letjend DI Panjaitan Road Section in Pemalang Regency.

\subsection{Research Population and Samples}

The population of this study was roads with flexible pavements which were damaged in Pemalang District. While the sample from this study is the Road Section of Letjend DI. Panjaitan in Pemalang Regency.

\subsection{Research Variables}

The variables of this study include the related variables, namely the level of damage to the pavement. And the variables are free, namely vehicle frequency, water, drainage. The parameters of this study are the types of road pavement damage processed by the Bina Marga method so as to produce damage level values, repair techniques and the amount of costs required for road repairs.

\subsection{Research data}

The research data collected in this study is the level of road damage on the Letjend DI Panjaitan route. Pemalang Regency, average daily traffic on the Letjend DI Panjaitan route Pemalang District and Job Unit Price Analysis as supporting data.

\section{RESULTS AND DISCUSSION}

3.1 Conditions of Pavement Based on the basic conditions of the Letjend DI Panjaitan route after assessment of road conditions with the Margin Development Method is obtained as follows: 


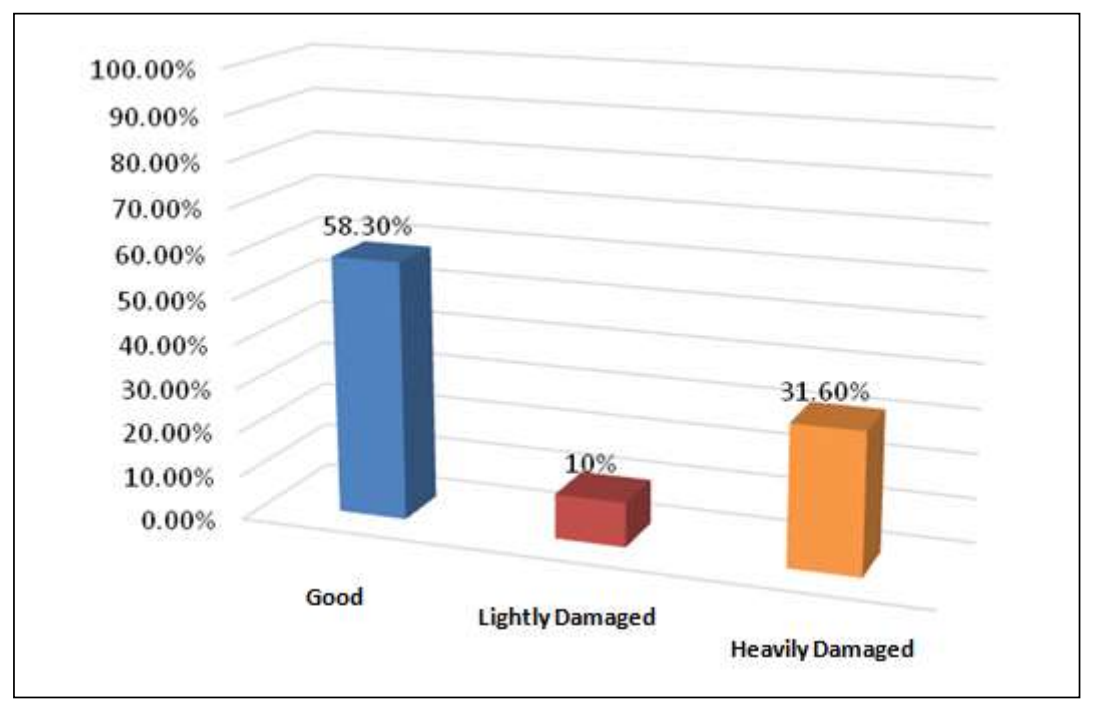

Fig 1. Graph of Pavement Conditions in Jalan Pemalang - Randudongkal

(Source: Field Research Results (2018)

\subsection{Repair Techniques}

\section{a. Improvements with Standard Repair Methods}

Improvements with the Standard Improvement Method are carried out on road concessions classified as good and light. The handling of road surface damage in the flexible layer uses the Standard Improvement Method of the Directorate General of Highways (1995). Recapitulation of handling damage for each damage for each segment as follows:

Table 1. Extensive Recapitulation of Road Damage Management

\begin{tabular}{llr}
\hline Type of Repair & Unit & Total \\
\hline P1 (Spread of Sand) & $\mathrm{m}^{2}$ & \\
P2 (Asphalt) & $\mathrm{m}^{2}$ & 802,389 \\
P3 (Crack Coating) & $\mathrm{m}^{2}$ & 154,5 \\
P4 (Crack Filling) & $\mathrm{m}^{2}$ & 72,97 \\
P5 (Hole Patching) & $\mathrm{m}^{2}$ & 709,203 \\
P6 (leveling) & $\mathrm{m}^{2}$ & 57,889 \\
\hline
\end{tabular}

Source: Field Research Results (2018)

\section{b. Repair with Rigid Pavement}

Rigid Pavement repairs were carried out on road concessions belonging to the improvement program. The repair area with Rigid Pavement was 7,600 m2. Rigid Pavement pavement thickness with a design life of 20 years is $25 \mathrm{~cm}$ obtained from the calculations of the Public Works Agency of Highways of Pemalang District.

\subsection{Determining Road Repair Costs}

Data on wage prices, materials and rental equipment used in this cost analysis are data from Construction Services and Middle Construction Information in 2017. Repair costs as follows: 
Table 2. Estimated Cost of Road Repair

\begin{tabular}{llllr} 
No. & Description & $\mathbf{2 0 1 8}$ Research & \multicolumn{2}{c}{$\begin{array}{c}\text { Bina Marga } \\
\text { standard }\end{array}$} \\
& & & 0.00 \\
\hline 1 & Standard Method & Rp. $147,243,400.00$ & Rp. \\
2 & Rigid Pavement & Rp. $2,733,685,154.00$ & Rp. 10,504,546,341.84 \\
\hline \multicolumn{3}{r}{ Tource: Calculation of 2018 and Pemalang Public Works Agency }
\end{tabular}

\section{CONCLUSION}

From the research conducted on the Letjend road section. DI Panjaitan in Pemalang Regency has a length of $3 \mathrm{~km}$ and after analysis and discussion, it can be concluded:

1. Based on the analysis of the level of damage to road conditions according to Bina Marga Standards is 58.30\% (good), 10\% (small damage), and 31.60\% (heavy damage);

2. To repair damaged and lightly damaged roads, repairs are needed with the 1995 Bina Marga Standard Improvement Method, while for the repair of heavily damaged roads, rigid pavements with $25 \mathrm{~cm}$ pavement thickness are needed.

3. Repair costs are Rp. 2,880,928,554.00 more economical $72.57 \%$ compared to the calculation of Bina Marga Standards using overall pavement repairs.

\section{ACKNOWLEDGMENT}

We would like to thank the leadership of the Civil Engineering Department of State Polytechnic of Semarang

\section{REFERENCES}

1. Directorate General of Highways. 1990. Procedures for Preparing the City Road Maintenance Program, No. 018 / T / $\mathrm{BNK} / 1990$.

2. Directorate of Public Works. 1995. Routine Maintenance Manual for National Roads and Provincial Roads, Volume II: Standard Improvement Method.

3. Saputro, Dian Agung. 2014. Determination of the Type of Selection of Road Maintenance with the Bina Marga Method (Case study: Jabung District, Malang Regency). Journal of Engineering Sciences - Systems, Vol. 10 No. 2, 1-6.

4. Saudule, Andre R. 2014. Analysis of the Causes of Road Damage (Case study: Jalan W. J. Lalamentik Section and Jalan Gor Flabomora Section). Civil Engineering Journal. Vol. III, No. 1, April 2014, 13-18. 